Hume, E. M. \& Krebs, H. A. (1949). Spec. Rep. Ser. med. Res. Coun., Lond., No. 264.

Husain, M. A. \& Mathur, C. B. (1936). Indian J. Agric. Sci. vi, 591.

Karrer, P. \& Würgler, E. (1943). Helv. chim. Acta. 26, 118.

Kuhn, R. \& Lederer, E. (1933). Ber. dtsch. chem. Ges. 66, 488.

Lederer, E. (1935). Les Carotenoides des Animaux. Paris: Hermann.

McCay, C. M. (1938). Physiol. Zool. 11, 89.

Mann, T. B. (1943). Analyst, 68, 233.
Mann, T. B. (1946). J. agric. Sci. 86, 289.

Przibram, H. \& Lederer, E. (1933). Anz. Akad. Wiss. Wien. $70,163$.

Suomalainen, P. (1939). Acta chem. fenn. 12B, 30.

Uda, H. (1919). Genetics, 4, 395.

Uvarov, B. P. (1921). Bull. ent. Res. $12,135$.

Uvarov, B. P. (1928). Locusts and Grasshoppers. A Handbook for Their Study. London: Imperial Burean of Entomology.

Uvarov, B. P. (1947). New Biology, 8, 9.

\title{
The Enzymic Degradation of Adenosinetriphosphate
}

\author{
By K. BAILEY, Biochemical Laboratory, University of Cambridge
}

(Received 16 May 1949)

The present investigation arose from the observation that samples of adenosinetriphosphate (ATP), freshly prepared from skeletal muscle, gave a satisfactory phosphate cleavage with myosin adenosinetriphosphatase, whilst samples stored as the barium salt at room temperatures were very deficient in this respect. By the use of a specific inorganic pyrophosphatase (Bailey \& Webb, 1944) it was later shown (Bailey \& Webb, unpublished) that such specimens contained as much as $12 \%$ of the labile phosphorus as inorganic pyrophosphate, indicating a breakdown of ATP to this latter substance and adenylic acid. It may be recalled that Lohmann (1928), before his characterization of ATP, considered the labile phosphorus of muscle to be inorganic pyrophosphate, and did in fact isolate the crystalline sodium salt. Later, he considered it to have arisen during the preparative procedure (Lohmann, 1931).

It is clear that ATP preparations decomposing in this way may show a satisfactory ratio of total phosphorus/labile phosphorus/total nitrogen, and other criteria of purity must be employed. For this purpose enzyme methods have been explored. The purity both of laboratory and commercial specimens of ATP has been assessed, and changes occurring during known conditions of storage have been followed.

\section{EXPERIMENTAL}

\section{Enzyme preparations}

Myosin adenosinetriphosphatase. Myosin was prepared in the conventional manner from rabbit muscle (see Bailey, 1942), and was five times precipitated from water. It was stored in $0.5 \mathrm{M}-\mathrm{KCl}$ at $\mathrm{pH} 7$ and $0^{\circ}$ in presence of a trace of toluene, and was efficient enzymically over a period of 3-4 weeks.

Myokinase. The method of preparation followed strictly that of Colowick \& Kalckar (1943). The enzyme was stored at $0^{\circ}$ as an ammonium sulphate filter cake, and dissolved in dilute veronal buffer ( $\mathrm{pH} 7$ ) before use. As a paste, the enzyme remains active indefinitely.

Yeast inorganic pyrophosphatase. The purified enzyme prepared by Bailey \& Webb (1944) was found to be active after storing at $0^{\circ}$ for 5 years. In the initial experiments, a new batch of crude enzyme was prepared from brewer's yeast. It was found that yeast autolysate, after dialysis, contained not only the very active pyrophosphatase, but also a weak, Mg-activated adenosinetriphosphatase. After submitting the autolysate to the first four stages of the fractionation procedure of Bailey \& Webb (1944), this latter enzyme had disappeared, leaving a very active pyrophosphatase suitable for the present work. Although the original enzyme has been used throughout, the preparation of new enzyme does not require the laborious procedure first employed. Preparations must be stored as an ammonium sulphate-protein paste at $0^{\circ}$.

Potato apyrase. This enzyme, discovered by Berger, Colowick \& Slein (unpublished; see Kalckar, 1944a), splits off two phosphate groups from ATP. In critical experiments, however, it was found that preparations made according to the directions of Kalckar (1944a) are feebly active with respect both to inorganic pyrophosphate and adenylic acid. Our findings are supported in a recent paper by Krishnan (1949), who has compared the substrate specificity of crude and purified enzyme. In high concentration, even the purified enzyme possesses nucleotidase activity, but not at concentrations which are still able to split off two phosphate groups from ATP. It would appear, therefore, that potato apyrase is mixed with other phosphatases, and the usefulness of this enzyme is somewhat limited.

\section{Incubation conditions}

General. After establishing the complete specificity of the enzyme preparations, three test systems were adopted: the splitting of ATP (a) by myosin adenosinetriphosphatase, (b) by myosin adenosinetriphosphatase in presence of myokinase, and (c) by yeast inorganic pyrophosphatase. Additional experiments with potato apyrase were sometimes carried out. In (a), only the terminal phosphate group is split, whilst in presence of myokinase the adenosinedi- 
phosphate (ADP) formed dismutes to adenylic acid and ATP, so that in the limit, the whole of the ATP is converted to adenylic acid. With pure ATP, the phosphate split by (a) should be half that of $(b)$, but if ADP is present initially as impurity, $(b)>2(a)$. Supposing also that inosinetriphosphate (ITP) is present, then, in absence of ADP impurity, (b) $<2(a)$, since ITP is degraded to inosinediphosphate (IDP) by adenosinetriphosphatase, but IDP is not attacked by myokinase (Kleinzeller, 1942). Indirect evidence for inorganic pyrophosphate impurity is also obtained if $2(a)$ or (b) fall far short of the values calculated from the labile $P$.

Without exception, tests were carried out in presence of excess enzyme, and the hydrolysis followed with a constant amount of enzyme over varying periods of time. Temperatures did not exceed $25^{\circ}$ to avoid inactivation (see below), but this possibility was always assumed, and additional enzyme was added to several tubes of a series towards the end of the incubation period.

Myosin and myokinase. A tube series must be used rather than a single incubation mixture, since the splitting of phosphate in presence of $\mathrm{Ca}$ activator gives rise to the progressive precipitation of $\mathrm{Ca}$ phosphate, and accurate sampling is impossible. Each tube contained $1 \mathrm{ml} .0 .5 \mathrm{M}$ glycine buffer (pH 8.6 at $20^{\circ}$ ), $0.1 \mathrm{ml} .0 .1 \mathrm{M}-\mathrm{CaCl}_{2}, 0.1 \mathrm{ml}$. myosin solution ( $0.5 \mathrm{mg}$. protein), Na-ATP solution $(0.2 \mathrm{mg}$. labile P), diluted with water to $1.6 \mathrm{ml}$. Another series was set up simultaneously, containing, in addition, myokinase (equivalent to $5 \mathrm{mg}$. protein paste). The tubes were incubated at $25^{\circ}$ and the reaction arrested by adding $0.5 \mathrm{ml}$. of $10 \%$ $(w / v)$ trichloroacetic acid. After standing at least $1 \mathrm{hr}$. in ice water, the protein was filtered off through small plugs of cotton wool into $25 \mathrm{ml}$. standard flasks, and the tubes washed with two $1 \mathrm{ml}$. portions of $3 \%$ trichloroacetic acid. The free phosphate, here and below, was measured colorimetrically in a photoelectric colorimeter by the FiskeSubbarow method.

Yeast pyrophosphatase and potato apyrase. The incubation conditions for the former have already been described (Bailey \& Webb, 1944). For the potato enzyme, 0.05 ml. $0 \cdot 1 \mathrm{M}-\mathrm{CaCl}_{2}$ was added to $2 \mathrm{ml}$. $0.03 \mathrm{~m}$-veronal (pH 7), followed by enzyme and ATP to a volume of $2.5 \mathrm{ml}$. With both enzymes deproteinization was unnecessary, and the reaction was arrested by addition of trichloroacetic acid to pH 1.

\section{Adenosinetriphosphate preparations}

Preparation. The general procedure followed that of Lohmann as described by Needham (1942). The dibarium salt, without drying, was acidified to $\mathrm{pH} 1$ with $\mathrm{HCl}$, separated from any insoluble residue, and precipitated as the monobarium salt with an equal volume of ethanol (cf. Kerr, 1941 a). The dibarium salt was again prepared by dissolving the monobarium salt in water and neutralizing with $\mathrm{NaOH}$ in presence of a slight excess of $\mathrm{Ba}$ acetate. After centrifuging, it was converted to the monobarium salt, which was finally dried in ethanol, ether, and in vacuo overnight. All preparations were stored at $0^{\circ}$.

Decomposition. When $\mathrm{Ba}^{++}$is removed as sulphate in the manner previously described (Bailey, 1942), there is a loss of $20 \%$ of the ATP which is adsorbed on the $\mathrm{BaSO}_{4}$. This loss may be minimized in the following way. Approximately

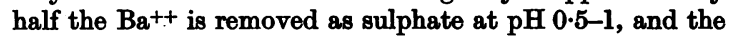
resulting solution run through a column of prepared Amberlite IR-100 (see Polis \& Meyerhof, 1947; Kielly \& Meyerhof, 1948). A solution equivalent to $0 \cdot 2-0 \cdot 3 \mathrm{~g}$. of
Ba-ATP can be employed for a $20 \mathrm{~cm}$. column containing $3 \mathrm{~g}$. of resin. The effluent emerges at $\mathrm{pH} 4 \cdot 5$, and is further neutralized to $\mathrm{pH} 6 \cdot 5$. (The resin is first activated by soaking in $5 \mathrm{~N}-\mathrm{HCl}$ overnight, washed with water, then with $4 \%$ $\mathrm{Na}_{2} \mathrm{CO}_{3}$ and finally with water; the column may be recovered thereafter by washing with $2 \mathrm{~N}-\mathrm{HCl}$.) The remo val of Fe ${ }^{+++}$in ATP preparations by resin is only partial, and in this respect an acid column is more efficient than that described.

\section{RESULTS}

The labile phosphorus of adenosinetriphosphate. Following the procedure of Lohmann (1931) most workers have determined the labile $\mathrm{P}$ by hydrolysing in $\mathrm{N}-\mathrm{HCl}$ for $7 \mathrm{~min}$. at $100^{\circ}$. Both Fiske (1934) and Kerr $(1941 a)$, on the other hand, recommend a

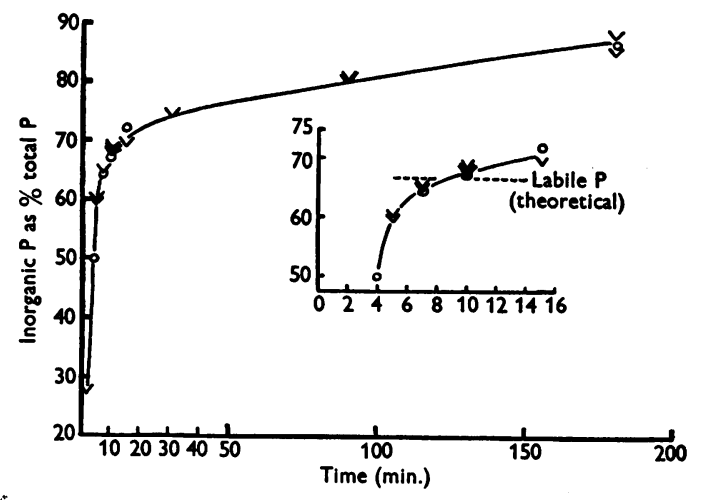

Fig. 1. Hydrolysis of ATP in $\mathrm{N}-\mathrm{HCl}$ (boiling water bath; $1 \mathrm{ml}$. samples). Inset: part of curve enlarged. $\mathrm{v}$, preparation 1 (3 experiments); O preparation 2 (1 experiment). Both samples prepared by author.

$15 \mathrm{~min}$. period. Whilst the shorter period of $7 \mathrm{~min}$. seems just sufficient for inorganic pyrophosphate, it gives values low by about $3 \%$ in the case of ATP (1 ml. samples). If the degradation of ATP by acid occurs partly at the terminal $\mathbf{P}$ group and partly at the penultimate, the ADP and inorganic pyrophosphate thus formed will themselves follow a unimolecular course of hydrolysis which will be complete in some period $>7 \mathrm{~min}$. The time at which labile $P$ is just two-thirds of the total $P$ will occur at a point where the $\mathbf{P}$ remaining in pyrophosphate linkage equals the phosphate contributed by the breakdown of adenylic acid (more strictly, of ribose5-phosphate). This point, according to present findings (Fig. 1), is $9-10 \mathrm{~min}$. after immersion of $1 \mathrm{ml}$. samples in boiling water.

Degradation of adenosinetriphosphate by myosin and myokinase. Fig. 2 illustrates the results of a typical experiment with a laboratory ATP preparation. A characteristic feature is the rapid initial splitting by adenosinetriphosphatase of $40 \%$ of the labile $\mathbf{P}$ (theory $50 \%$ ), and thereafter a slow decomposition to the final value. The latter phase could 
represent: $(a)$ a low rate of hydrolysis at low substrate concentration, (b) inhibition by ADP, (c) inhibition by phosphate. The points lying near curve $A$, Fig. 2, show that ATP in low concentration, either alone or in presence of a large excess of ADP, is rapidly split, but that in presence of inorganic phosphate, the breakdown is relatively slow. The inhibition by free phosphate may be more apparent than real, since in the later stages of the reaction $\mathrm{Ca}$ phosphate is precipitated. The facility with which

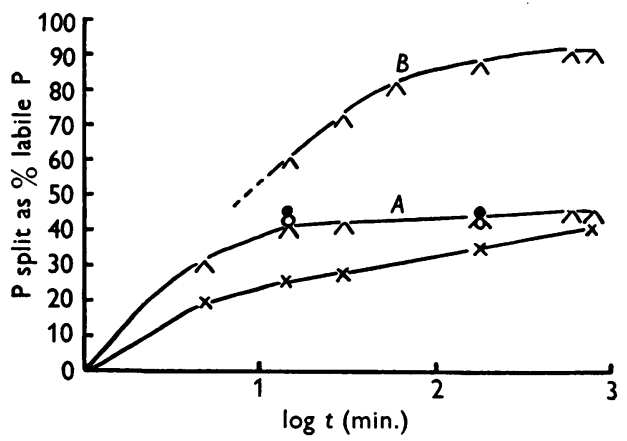

Fig. 2. Hydrolysis of a fresh specimen of laboratory ATP by enzymes. $A$, adenosinetriphosphatase; $B$, adenosinetriphosphatase-myokinase; each curve represents hydrolysis of ATP equiv. to $0.17 \mathrm{mg}$. labile P. $0,0.05 \mathrm{mg}$. labile $P$ of ATP without additions; $O, 0.05 \mathrm{mg}$. labile $P$ of ATP + 0.23 mg. labile P of ADP; $x-\times, 0.024 \mathrm{mg}$. labile $P$ of ATP $+0.23 \mathrm{mg}$. inorganic phosphate; all in presence of adenosinetriphosphatase alone.

nucleotides form double salts makes it possible that some ATP is adsorbed by this precipitate and is less accessible to the enzyme. The addition of inorganic pyrophosphate in amounts sometimes found in ATP preparations (see below) has no significant effect upon the initial or final rates of splitting.

After $10 \mathrm{hr}$. at $25^{\circ}$, the splitting in the presence of myosin and myokinase (curve $B$, Fig. 2) is $92 \%$ of the labile $\mathrm{P}$, and that with myosin alone (curve $A$ ), $47 \%$. After this period, the enzymes are still capable of splitting added ATP, so that the cessation of hydrolysis must be due either to the attainment of an equilibrium, apparent or real, or to the presence of impurities. These points are more appropriately discussed below.

Inorganic pyrophosphate in adenosinetriphosphate preparations. Referring to his previous isolation of sodium pyrophosphate from muscle, Lohmann (1931) comments: 'The former investigations were in error, through the spontaneous decomposition of this compound (ATP) as the Ba salt in neutral or weakly alkaline solutions.' This warning as to the instability of ATP seems generally to have been ignored. When tested with yeast pyrophosphatase, old preparations of ATP which contained labile phosphate unavailable either to myosin or for the phosphorylation of glucose by yeast hexokinase, were found to contain inorganic pyrophosphate (Bailey \& Webb, unpublished). The unique affinity of pyrophosphatase for its substrate gives a progress curve which is linear almost to the point where substrate is exhausted (Bailey \& Webb, 1944). This effect is shown again in Fig. 3 where progress curves

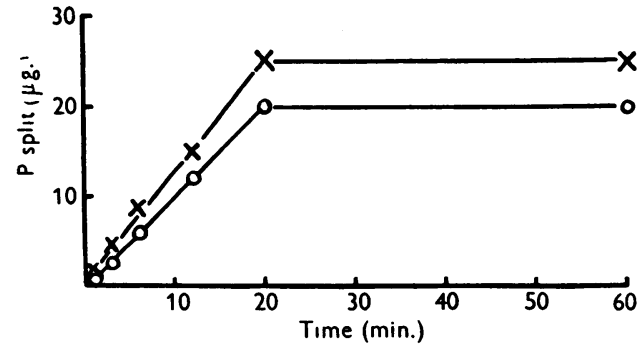

Fig. 3. Hydrolysis of inorganic pyrophosphate by yeast pyrophosphatase. $\quad \times-\times, \quad \mathrm{Na}_{4} \mathrm{P}_{2} \mathrm{O}_{7} ; \mathrm{O}-\mathrm{O}$, pyrophosphate in a stored commercial ATP preparation.

are given for pyrophosphate comparable in concentration to that found in a commercial ATP preparation which had been stored at room temperature for an unknown period. The absolute specificity of the enzyme, and the similar slopes, make it certain that the component degraded is inorganic pyrophosphate.

Table 1. Enzymic assay of inorganic pyrophosphate produced during storage of adenosinetriphosphate samples

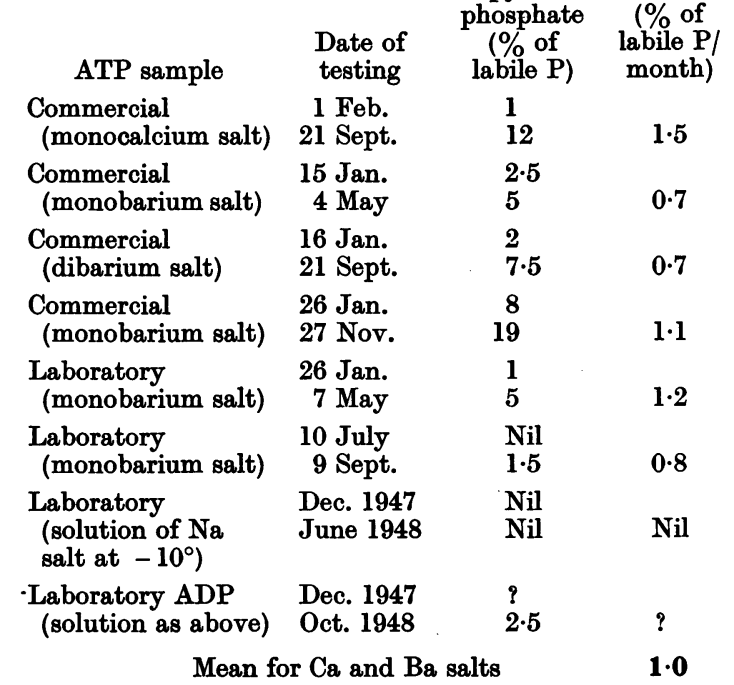

Both monobarium and dibarium salts, as also the Ca salt, break down progressively to pyrophosphate and adenylic acid on storage, even at $0^{\circ}$. Table 1 summarizes the pyrophosphate content of various 
ATP preparations after storing at $0^{\circ}$. As a percentage of the labile $P$, the rate of production of inorganic pyrophosphate/month varies between the extremes of 0.7 and $1.5 \%$, mean $1.0 \%$. Whether the water content of the preparations influences breakdown has not been determined. In contrast, no pyrophosphate has been detected after storing solutions of Na-ATP at $\mathrm{pH} \mathrm{6.5} \mathrm{in} \mathrm{the} \mathrm{frozen} \mathrm{state} \mathrm{even}$ after 7 months, and only $2.6 \%$ in a preparation of ADP similarly stored (this may have been present originally).

Analysis of some adenosinetriphosphate preparations. In Table 2 are collected chemical and enzymic analyses of laboratory and commercial ATP preparations. The ratio total $\mathbf{P} /$ labile $\mathbf{P}$ (each corrected
The labile $\mathbf{P}$ accounted for enzymically is never more than 93-95\%, even in laboratory preparations. Commercial preparations generally contain more free $\mathbf{P}$ and inorganic pyrophosphate, and show a lower raite of splitting with myosin-adenosinetriphosphatase. To check whether the enzyme assay gives a true measure of purity, the end products were isolated and again subjected to enzyme action. The assay by the muscle enzymes was also compared with the action of potato apyrase.

The action of potato apyrase on adenosinetriphosphate. Kalckar (1944a) records that the terminal group of ATP is split faster than that of ADP. The progress curve, given in Fig. 4, consists of two portions, the first representing mainly the splitting of

Table 2. Chemical and enzymic analysis of commercial and laboratory preparations of adenosinetriphosphate

\begin{tabular}{|c|c|c|c|c|c|c|c|c|}
\hline \multirow[b]{2}{*}{ Source } & \multirow[b]{2}{*}{ Type of salt } & \multirow[b]{2}{*}{$\begin{array}{c}\text { Total P } \\
(\%)\end{array}$} & \multicolumn{3}{|c|}{$\begin{array}{l}\text { Chemical analysis as } \\
\text { percentage of total } \mathrm{P}^{*}\end{array}$} & \multicolumn{3}{|c|}{$\begin{array}{l}\text { Enzymic analysis as percentage } \\
\text { of labile ( } 10 \mathrm{~min} .) \mathrm{P}\end{array}$} \\
\hline & & & Labile P & Free $\mathbf{P}$ & $\begin{array}{l}\text { Ratio } \\
\text { total P/ } \\
\text { labile P }\end{array}$ & ATPaset & $\begin{array}{c}\text { ATPase }+ \\
+ \\
\text { myokinase }\end{array}$ & $\begin{array}{c}\text { Pyro- } \\
\text { phosphatase } \\
\text { (yeast) }\end{array}$ \\
\hline $\begin{array}{l}\text { Author } \\
\text { (fresh samplef) }\end{array}$ & Monobarium & 11.95 & $7 \cdot 85$ & 0.05 & 1.52 & $44 \cdot 5$ & 92 & 1 \\
\hline $\begin{array}{l}\text { As above } \\
\text { (stored } 3 \text { months) }\end{array}$ & & - & - & - & - & 43 & 86 & 5 \\
\hline $\begin{array}{l}\text { Author } \\
\text { (stored } 6 \text { weeks) }\end{array}$ & Monobarium & $11 \cdot 0$ & $7 \cdot 55$ & $0 \cdot 14$ & $1 \cdot 46$ & $41 \cdot 5$ & $91 \cdot 5$ & 1.5 \\
\hline E.J.M. & Monobarium & - & - & - & - & 46 & 92 & 1.5 \\
\hline $\begin{array}{l}\text { Commercial } \\
\text { (stored } 1 \text { yr.) }\end{array}$ & Monobarium & $11 \cdot 67$ & 8.25 & 0.8 & 1.41 & $34 \cdot 5$ & 71 & 19 \\
\hline $\begin{array}{l}\text { Commercial } \\
\text { (fresh) }\end{array}$ & Dibarium & 8.95 & $5 \cdot 75$ & $1 \cdot 3$ & $\begin{array}{l}1 \cdot 55 \\
(1 \cdot 45)\end{array}$ & 43 & 87 & 2 \\
\hline $\begin{array}{l}\text { As above, stored } \\
4 \text { months }\end{array}$ & & - & - & - & - & 38 & 82 & $\mathbf{7 \cdot 5}$ \\
\hline $\begin{array}{l}\text { Author (stored } 2 \text { yr. } \\
\text { at room temp.) }\end{array}$ & Dibarium & $9 \cdot 65$ & $5 \cdot 4$ & 2.5 & $\begin{array}{l}1.79 \\
(1.53)\end{array}$ & 18 & $51 \cdot 5$ & 41 \\
\hline $\begin{array}{l}\text { Advanced class } \\
\text { (stored } 5 \text { yr. at } \\
\text { room temp.) }\end{array}$ & Dibarium & $7 \cdot 76$ & $4 \cdot 72$ & 1.55 & $\begin{array}{l}1 \cdot 64 \\
(1 \cdot 48)\end{array}$ & $\mathrm{Nil}$ & $2(?)$ & $95 \cdot 5$ \\
\hline
\end{tabular}

for inorganic phosphate) is near the theoretical value of 1.5 in fresh laboratory specimens. Where the preparations have been stored, the free inorganic phosphate is high, and the ratio is only satisfactory if this latter is added both to labile and total $P$. This fact alone indicates some breakdown to ADP and phosphate, and the enzymic analyses support the inference; i.e. in these cases the splitting by myosin + myokinase is more than twice that with myosin alone, indicating the presence of free ADP. The breakdown of ATP to inorganic pyrophosphate on storage is thus accompanied by a less extensive de. composition to ADP and phosphate. the terminal phosphate of ATP, and the second that of ADP. A break occurs when most of the ATP is degraded to ADP and another when hydrolysis is complete. A somewhat similar curve was obtained by Albaum \& Kletzkin (1948) with ATP from Drosophila melanogaster. The total splitting is $7 \%$ above that obtained with myosin + myokinase, but of the $5 \%$ inorganic pyrophosphate present, 2-3\% will have undergone hydrolysis by the pyrophosphatase present in the potato enzyme. Under the conditions of the experiment, the nucleotidase action can be neglected. (Initial hydrolysis rates of ATP, Na pyrophosphate and adenylic acid by apyrase are in the 
ratio $1,0.01$ and 0.003 respectively.) Thus, it would appear that the true ATP content is some $4 \%$ higher than that indicated by use of the muscle enzymes. This figure is vindicated by experiments with ATP preparations containing no inorganic pyrophosphate, and by the isolation experiments below.

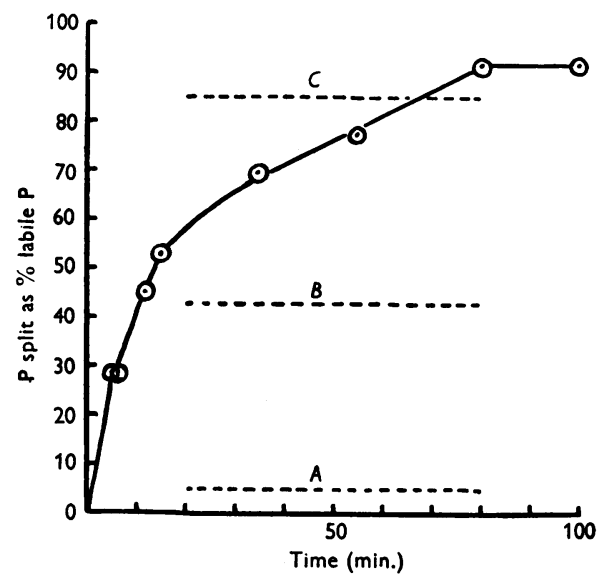

Fig. 4. Hydrolysis of ATP by potato apyrase. Dotted curves: $A$, level of splitting with yeast pyrophosphatase; $B$, with adenosinetriphosphatase; $C$, with adenosinetriphosphatase-myokinase.

\section{Isolation of end products after the action of myosin or myosin plus myokinase}

The ATP solution is incubated for about $7 \mathrm{hr}$. at $25^{\circ}$ with myosin (or myosin + myokinase) under the standard conditions. The digest is adjusted to $\mathrm{pH} 5$ with $\mathrm{HCl}$, the precipitate of protein centrifuged off and the extent of hydrolysis determined on a sample of the supernatant liquid. An excess of Ba acetate (final concentration $0.1 \%$ ) is added and $\mathrm{NaOH}$ to a $\mathrm{pH}$ of 7 , followed by ethanol to a final concentration of $50 \%(\nabla / v)$. After cooling to $0^{\circ}$, the Ba salts are centrifuged down, suspended in water, and $\mathrm{HNO}_{3}$ added to pH 1. The nucleotides are now precipitated in the usual manner (cf. Needham, 1942) with the Lohmann mercury reagent, decomposed with $\mathrm{H}_{8} \mathrm{~S}$ and neutralized (after aeration) with $\mathrm{Ba}$ acetate and $\mathrm{NaOH}$ (final $\mathrm{pH} 7 \cdot 5$ ). After addition of an equal volume of ethanol, the $\mathrm{Ba}$ salts are separated, dried in ethanol and ether, and subjected to enzymic analysis.

Table 3 summarizes the results of three experiments, two with the end products after the action of myosin alone, and one after myosin + myokinase. The recovery of labile $P$ in the case of the first two experiments is $60-80 \%$ of the calculated amount, and most of the inorganic pyrophosphate present is recovered. The recovery of labile $\mathbf{P}$ from myosinmyokinase digests, on the other hand, is always low, and most of the inorganic pyrophosphate is now not precipitated with the Lohmann reagent. (This again illustrates how readily the nucleotides form double salts (cf. Kerr, 1941b).) The recovery of any undecomposed ATP is probably greater than the overall figures for the total recovery of labile $P$, so that the values derived in columns (b) of Table 3 , corrected for isolation losses, are maximal. They indicate that the assay of ATP by the muscle enzymes is 1-2.5\% low. In the best laboratory preparations, therefore, some 4-5\% of the labile $P$ has not been identified (see Table 2).

A possible impurity was at first thought to be guanylic acid, which according to Kerr \& Seraidarian (1945) is present in the trichloroacetic extracts of various tissues, though the amount in skeletal muscle (dog) amounts only to $3 \%$ of the adenine nucleotides. This probably arises by

Table 3. Isolation and analysis of the end products after enzymic breakdoun of adenosinetriphosphate

(All values expressed as percentage of labile phosphorus.)

\begin{tabular}{|c|c|c|c|c|c|c|c|c|c|}
\hline \multirow{3}{*}{$\begin{array}{l}\text { ATP sample } \quad \text {... } \\
\text { Method of degradation }\end{array}$} & \multirow{3}{*}{$\cdots$} & \multirow{3}{*}{$\cdots$} & \multirow{3}{*}{$\cdots$} & \multicolumn{2}{|c|}{ Exp. 1} & \multicolumn{2}{|c|}{ Exp. 2} & \multicolumn{2}{|c|}{ Exp. 3} \\
\hline & & & & \multicolumn{2}{|c|}{ Laboratory } & \multicolumn{2}{|c|}{ Commercial } & \multicolumn{2}{|c|}{ Commercial } \\
\hline & & & & \multicolumn{2}{|c|}{ ATPase* } & \multicolumn{2}{|c|}{ ATPase* } & \multicolumn{2}{|c|}{$\begin{array}{l}\text { ATPase*. } \\
\text { myokinase }\end{array}$} \\
\hline \multicolumn{10}{|l|}{ Original analysis: } \\
\hline \multicolumn{4}{|c|}{$\begin{array}{l}\text { Split by adenosinetriphosphatase } \\
\text { Split by adenosinetriphosphatase-myokinase } \\
\text { Split by pyrophosphatase (yeast) }\end{array}$} & \multicolumn{2}{|c|}{$\begin{array}{l}46 \\
92 \\
1 \cdot 5\end{array}$} & \multicolumn{2}{|c|}{$\begin{array}{l}33 \\
69 \cdot 5 \\
14 \cdot 5\end{array}$} & \multicolumn{2}{|c|}{$\begin{array}{l}36 \cdot 5 \\
80 \cdot 5 \\
12 \cdot 0\end{array}$} \\
\hline \multicolumn{10}{|c|}{ Analysis of large-scale digest: } \\
\hline \multicolumn{4}{|c|}{$\begin{array}{l}\text { Labile } P \text { split } \\
\text { Labile } P \text { recovered as percentage of calc. value }\end{array}$} & \multicolumn{2}{|c|}{$\begin{array}{l}45 \\
79\end{array}$} & \multicolumn{2}{|c|}{$\begin{array}{l}33 \\
61\end{array}$} & \multicolumn{2}{|c|}{80} \\
\hline \multicolumn{4}{|c|}{ Analysis of recovered end products: $\ddagger$} & $(a)$ & $(b)$ & $(a)$ & (b) & $(a)$ & (b) \\
\hline \multicolumn{4}{|c|}{$\begin{array}{l}\text { Split by adenosinetriphosphatase } \\
\text { Split by adenosinetriphosphatase-myokinase } \\
\text { Split by pyrophosphatase }\end{array}$} & $\begin{array}{r}4 \\
88 \\
4\end{array}$ & $\frac{2 \cdot 4}{-}$ & $\begin{array}{l}2 \cdot 5 \\
64 \\
25\end{array}$ & $\frac{1 \cdot 8}{-}$ & $\begin{array}{l}2 \cdot 5 \\
14 \cdot 5 \\
45 \S\end{array}$ & $\frac{1 \cdot 2}{-}$ \\
\hline
\end{tabular}

* ATPase = adenosinetriphosphatase.

+ Recovery here on the basis of labile $P$ other than inorganic pyrophosphate.

$\ddagger$ Values $(a)$ as percentage of labile $\mathbf{P}$ present in the isolated end products; $(b)$ as percentage of original labile $\mathbf{P}$ of digest after correction for isolation losses.

$\S$ Of the original inorganic pyrophosphate- $95 \%$ was recovered from the water-soluble $\mathrm{Hg}$ salts. 
degradation of tissue nucleic acid in trichloroacetic acid (cf. Kaplan \& Neuberg, 1944). When ATP is hydrolysed for $10 \mathrm{~min}$. in $\mathrm{N}-\mathrm{HCl}$, a substance is liberated which gives a blue colour with the Folin phenol reagent in alkali, though the original ATP contains no chromogenic material. If the latter were a chromogenic purine (guanine or xanthine) liberated from glycosidic linkage, the amount should remain constant after $15 \mathrm{~min}$. when hydrolysis is virtually complete. It was found, however, that the amount steadily increased with continued hydrolysis, and that pure adenine itself was transformed in the same way. This reaction is worthy of further study.

Control experiments had shown that under the conditions of incubation of ATP in alkaline glycine buffer, no degradation to inorganic pyrophosphate or free phosphate occurred. The possibility that some of the missing labile $P$ had arisen by the enzymic production of pyrophosphate was also checked. In these experiments, it was necessary to acidify the myosin-myokinase digests to $\mathrm{pH} 5$ to inactivate adenosinetriphosphatase, to reneutralize to $\mathrm{pH} \mathrm{7,} \mathrm{add} \mathrm{veronal}$ buffer $\mathrm{pH} \mathrm{7,} \mathrm{and} \mathrm{to} \mathrm{swamp} \mathrm{the} \mathrm{Ca}^{++}$with a tenfold concentration of $\mathrm{Mg}^{++}$to allow the action of pyrophosphatase, which is antagonized by $\mathrm{Ca}^{++}$(Bailey \& Webb, 1944). The difference in free phosphate before and after addition of pyrophosphatase was always within the experimental error. It was also shown that digests hydrolysed to the fullest extent, either by myosin or myosin-myokinase, and then subjected to $10 \mathrm{~min}$. hydrolysis in acid, contained the amount of labile $P$ added at the beginning of the experiment. None is lost, therefore, by transfer to a more stable form.

Adenosinediphosphate in muscle. Since ADP functions as phosphate acceptor in several reactions of the glycolytic cycle, and also as the substrate for myokinase, it seems unlikely that any appreciable

Table 4. Enzymic analysis of the crude barium salts from trichloroacetic extracts of muscle

\begin{tabular}{|c|c|c|c|}
\hline \multirow[b]{2}{*}{$\begin{array}{c}\text { Muscle } \\
\text { (rabbit) }\end{array}$} & \multirow[b]{2}{*}{$\begin{array}{c}\text { Mode of } \\
\text { preparation }\end{array}$} & \multicolumn{2}{|c|}{$\begin{array}{l}\text { Phosphate split as } \\
\text { percentage labile P }\end{array}$} \\
\hline & & ATPase* & $\begin{array}{c}\text { ATPase*. } \\
\text { myokinase }\end{array}$ \\
\hline Fresh & $\begin{array}{l}\text { Ba salts pptd. at } \\
\text { pH } 6.5 \text {, washed twice }\end{array}$ & 41 & 81 \\
\hline Fresh & $\begin{array}{l}\text { As above, then pptd. } \\
\text { in ethanol-HCl }\end{array}$ & $45 \cdot 5$ & 91 \\
\hline $\begin{array}{l}\text { Stood } 5 \mathrm{hr} . \\
\text { at } 15^{\circ}\end{array}$ & $\begin{array}{l}\text { Ba salts pptd. at } \\
\text { pH 6.5, washed twice }\end{array}$ & $35 \dagger$ & $70 \dagger$ \\
\hline $\begin{array}{l}\text { Stood } 5 \mathrm{hr} \text {. } \\
\text { at } 15^{\circ}\end{array}$ & $\begin{array}{l}\text { As above, then pptd. } \\
\text { in ethanol-HCl }\end{array}$ & 44 & 88 \\
\hline
\end{tabular}

concentration ever exists in mucle. Trichloroacetic extracts of fresh and rigor muscle were examined for the presence of $\operatorname{ADP}(a)$ by analysing the Ba salts precipitated at $\mathrm{pH} 7$ and again after removal of free phosphate $(b)$. No evidence of ADP in identifiable amounts was found in these crude fractions (Table 4). Method $(a)$ suffers from the disadvantage that the large amounts of free phosphate present make enzymic analysis difficult, whilst in (b) some ADP may be lost in the ethanol-HCl procedure used for the removal of phosphate. The presence of a small amount of ADP can, however, be shown in the mother liquors obtained after precipitating ATP.

The once-precipitated Ba salt of ATP (11.9 g.) was dissolved in $30 \mathrm{ml}$. $\mathrm{N}-\mathrm{HCl}$, diluted with water and precipitated as the dibarium salt (total volume $1 \cdot 21$.). The precipitate was spun down, dissolved in $\mathrm{HCl}$ (total volume $500 \mathrm{ml}$., pH 2) and an equal volume of ethanol added. The combined mother liquors were neutralized to $\mathrm{pH} \mathrm{7 \cdot 5}$, an equal volume of ethanol added, and the precipitated $\mathrm{Ba}$ salt dried and decomposed. Enzymic analysis gave (as percentage of the labile P): split by myosin, $23 \%$; by myosin-myokinase, $88 \%$; by pyrophosphatase, $4 \%$. Of the labile $P, 42 \%$ thus existed as ADP, corresponding to $1.1 \%$ of the labile $\mathrm{P}$ of the original ATP.

Allowing that the starting material had been subjected to some purification, and that the final product might still contain some ADP, the true ADP content cannot exceed this figure greatly, since larger amounts (up to $5 \%$ of the total labile $\mathrm{P}$ ) would be discovered by direct enzymic assay of the main ATP preparation. By contrast, Kalckar (1947) infers that considerable amounts of ADP are present in guinea-pig and hamster muscle.

\section{DISCUSSION}

\section{The purity and stability of adenosinetriphosphate}

The present results indicate that ATP preparations made by current modifications of the Lohmann method and precipitated 2-4 times are at least $95 \%$ pure. When freshly prepared they contain less than $1 \%$ inorganic pyrophosphate, which increases on storage at $0^{\circ}$ at the rate of $1 \% /$ month. Both calcium and barium salts are subject to this change, and one sample of a dry sodium salt, stored at room temperature for a long period, had entirely decomposed. A less extensive breakdown to ADP and phosphate also occurs. If ATP samples have been prepared via the monocalcium or monobarium salt, the presence of free phosphate is itself indicative of extensive decomposition.

The complete enzymic assay of ATP preparations before use for other purposes may not always be possible. In this case, it is advisable to use ATP samples of known history and to check the extent of decomposition with yeast pyrophosphatase. This latter enzyme can be prepared in a form which is stable over many years, and the amounts required do not necessitate deproteinization.

It has not been possible to extend the investigation to the effect of water content on the decomposition of ATP salts, though negligible breakdown occurs when solutions of the sodium salt are stored at $-10^{\circ}$. Recently, it has been found that ATP can be precipitated quantitatively as the benzidine salt 
from aqueous ethanol at acid $\mathrm{pH}$, and is quantitatively recovered by decomposing the complex with sulphuric acid, which forms the insoluble benzidine sulphate. The decomposition of bariumATP, on the other hand, always involves some loss of nucleotide, whilst that of the acridine compound necessitates ether extraction. These advantages of benzidine as a precipitant for ATP will be enhanced if the complex is found to be more stable than the metallic salts of ATP.

\section{The enzyme systems}

Whilst the use of myosin adenosinetriphosphatase alone, and in conjunction with myokinase, is in theory ideal for the determination of mixtures of ATP and ADP, the practical application is more difficult than was at first realized (cf. Bailey, 1948 a). The main disadvantage lies in the slow hydrolysis of ATP by adenosinetriphosphatase in the later stages of the reaction, when the substrate is almost exhausted and inorganic phosphate has accumulated. Previous workers (e.g. Rapoport \& Nelson, 1945) who have used myosin for the assay of ATP in biological material do not seem to have been aware of this effect, which is probably due to adsorption of ATP on the precipitated calcium phosphate. The long incubations necessary for the assay of ATP by adenosinetriphosphatase $\left(7-10 \mathrm{hr}\right.$. at $\left.25^{\circ}\right)$ demand that the myosin be free from myokinase, and 4-5 precipitations are essential.

As an alternative to the use of myosin, potato apyrase is not entirely specific, and shows a feeble inorganic pyrophosphatase activity, and a still feebler action upon adenylic acid. Except for very precise analysis, these disadvantages are not serious. The usefulness of apyrase has been fully demonstrated by Kalckar (1944b), who has been able to differentiate the two labile phosphate groups of ATP in which ${ }^{32} \mathrm{P}$ had been incorporated. The terminal group was isolated by the yeast hexokinase reaction and both groups by the action of apyrase. The same differentiation or, if need be, the assay of mixtures of ADP and ATP, can be achieved by the use of hexokinase acting singly and in conjunction with myokinase (Kalckar, 1943). Unfortunately, the preparation of pure yeast hexokinase is a formidable task (cf. Bailey \& Webb, 1948), and less pure preparations may be contaminated with adenosinetriphosphatase (Kielly \& Meyerhof, 1948). Kalckar (1947) later made use of apyrase in the development of an optical micromethod for the determination of adenine compounds, basing the method upon the marked change in the ultraviolet absorption when adenine, free or combined, is deaminated to hypoxanthine. In this way adenylic acid can be estimated after the action of muscle deaminase, ADP by myokinase in conjunction with deaminase, and ATP by apyrase and deaminase.
Finally, some mention must be made of the claims of Banga (1947) and of Banga \& Josepovits (1947 $a, b$ ) with respect to the action of myosin on ATP. It is claimed that part of the ATP is degraded to ADP and part utilized in the formation of a dinucleoside pentaphosphate. The isolated dinucleotide shows some splitting in presence of myosin, but the production of inorganic phosphate is much greater in presence of myosin plus 'protein $\mathrm{II}$ '. The latter, as already pointed out (Bailey, 1948b), exhibits many of the properties of myokinase, and there is nothing in its manner of preparation which suggests its elimination. The obvious explanations for these results seem to have been meticulously avoided. First, in the action of myosin on ATP, only $33 \%$ of the labile phosphorus is split, and the manner of isolation of the end products would give a product containing a mixture of ATP, ADP and inorganic pyrophosphate (if present). The renewed action of myosin itself on this mixture would affect only the ATP component, but acting in conjunction with protein II (myokinase), both ATP and ADP would be degraded to adenylic acid and inorganic phosphate.

Secondly, ammonia formation indicates the presence of adenylic acid deaminase in protein II. When the latter is added to the mixture, the ADP already present dismutes to ATP and adenylic acid by the action of myokinase, and the adenylic is at once deaminated. The deamination process itself speeds up the dismutation by removing one component of an equilibrium mixture, so that the initial formation of ammonia would be very rapid. This was actually observed. Later, ammonia production keeps pace with the splitting of phosphate, and this too can be explained, since the production of ADP, and hence of adenylic acid, is controlled by the hydrolysis of ATP by myosin, which becomes the limiting reaction. The overall reaction is

$$
\text { ATP } \rightarrow 2 \mathrm{PO}_{4}^{\sharp}+\mathrm{NH}_{3}+\text { inosinic acid. }
$$

Expressed as a percentage of the total labile phos. phorus and total amino nitrogen respectively, the liberation of free phosphorus and of ammonia must coincide. The results do not support the claim of Banga \& Josepovits (1947b) that the action of myosin on ATP produces, in addition to the dinucleotide, an isomeric ADP in which a phosphate group is linked to the amino group of adenine. Not only are Banga's results unwarranted on the experimental evidence, but they can readily be explained in terms of known enzyme systems.

\section{SUMMARY}

1. The enzymic assay of adenosinetriphosphate and adenosinediphosphate, either singly or in mixtures, has been explored by use of myosin adenosinetriphosphatase acting alone and in conjunction with 
myokinase. A disadvantage of the method is the slow hydrolysis of adenosinetriphosphate in the final stages of the reaction.

2. Metallic salts of adenosinetriphosphate are shown to be unstable and break down on storage to adenylic acid and inorganic pyrophosphate, and to a less extent to adenosinediphosphate and inorganic phosphate.

3. The best preparations of adenosinetriphosphate are at least $95 \%$ pure. The possibility that some impurity is present is not excluded.
4. The use of potato apyrase for the assay of adenosinetriphosphate is restricted by its contamination with a nucleotidase and an inorganic pyrophosphatase.

5. Both in fresh and in rigor muscle, the adenosinediphosphate present is less than $5 \%$ and probably greater than $1 \%$ of the labile nucleotide phosphorus.

6. The claims of Banga concerning the action of muscle enzymes on adenosinetriphosphate are criticized.

\title{
REFERENCES
}

Albaum, G. H. \& Kletzkin, M. (1948). Arch. Biochem. 16, 333.

Bailey, K. (1942). Biochem. J. 36, 121.

Bailey, K. (1948a). Biochem. J. 42, lviii.

Bailey, K. (1948b). Nature, Lond., 160, 550.

Bailey, K. \& Webb, E. C. (1944). Biochem. J. 38, 294.

Bailey, K. \& Webb, E. C. (1948). Biochem. J. 42, 60.

Banga, I. (1947). Hungarica Acta Physiol. 1, 72.

Banga, I. \& Josepovits, G. (1947a). Hungarica Acta Physiol. 1, 67.

Banga, I. \& Josepovits, G. (1947b). Hungarica Acta Physiol. 1, 82.

Colowick, S. P. \& Kalckar, H. M. (1943). J. biol. Chem. $148,117$.

Fiske, C. H. (1934). Proc. nat. Acad. Sci., Wash., 20, 25.

Kalckar, H. M. (1943). J. biol. Chem. 148, 127.

Kalckar, H. M. (1944a). J. biol. Chem. 153, 355.
Kalckar, H. M. (1944b). J. biol. Chem. 154, 267, 275.

Kalckar, H. M. (1947). J. biol. Chem. 167, 445.

Kaplan, N. O. \& Neuberg, D. M. (1944). J. biol. Chem. 156, 511.

Kerr, S. E. (1941a). J. biol. Chem. 139, 121.

Kerr, S. E. (1941b). J. biol. Chem. 139, 131.

Kerr, S. E. \& Seraidarian, K. (1945). J. biol. Chem. 159, 637.

Kielly, W. W. \& Meyerhof, O. (1948). J. biol. Chem. 176, 591.

Kleinzeller, A. (1942). Biochem. J. 36, 729.

Krishnan, P. S. (1949). Arch. Biochem. 20, 261, 272.

Lohmann, K. (1928). Biochem. Z. 202, 466.

Lohmann, K. (1931). Biochem. Z. 233, 460.

Needham, D. M. (1942). Biochem. J. 36, 113.

Polis, D. B. \& Meyerhof, O. (1947). J. biol. Chem. 169, 389.

Rapoport, S. \& Nelson, N. (1945). J. biol. Chem. 161, 421.

\section{Preparation of the Antibiotic Nisin}

\author{
By N. J. BERRIDGE \\ National Institute for Research in Dairying, University of Reading
}

(Received 20 May 1940)

The early pharmacological work with nisin, prepared from Streptococcus lactis (Lancefield group N) (Mattick \& Hirsch, 1947) was remarkable for the success which attended the use of crude concentrates. Nevertheless, it was obvious that more potent material would be required for human therapy and for experiments with the less sensitive pathogens. A note (Berridge, 1947) added to the paper of Mattick \& Hirsch showed that highly active preparations in the form of crystals or tactoids could conveniently be made. The details of a number of such preparations are now described.

\section{METHODS}

(1) The unit of antibiotic activity. A preparation of nisin powder was chosen as a standard, and its activity defined as 1.3 units/ $\mu$ g.; 1 unit will normally just inhibit the growth of the test organism, Strep. agalactiae, in $1 \mathrm{ml}$. of broth (test Ai), and is roughly equal to the unit of Mattick \& Hirsch.

(2) Measurement of antibiotic activity. Three tests were given a prolonged trial during this work. A, Bacteriostatic tests: (i) dilutions of the antibiotic in powers of 2 in inoculated broth, with the recording of growth after $16 \mathrm{hr}$. and $40 \mathrm{hr}$. as,+++ or +++ ; (ii) dilution of the antibiotic in powers of 1.3-1.5 in broth or skim milk heavily seeded with sensitive acid-forming organisms with the recording of $\mathrm{pH}$ after 10-16 hr. incubation; and $B$, an apparently bactericidal test in which the proportion of organisms surviving a few minutes' contact with the antibiotic diluted in powers of 4 was determined by the plate count. It is quite possible that different activities were measured by the different methods. The details of the methods are as follows:

Method Ai. This did not differ significantly from that described by Mattick \& Hirsch (1947).

Method A ii. The nisin samples were diluted on the basis of an assumed activity to give solutions with about 10 units/ ml. Suitably spaced volumes (e.g. from $0.08 \mathrm{ml}$. increasing 